\title{
EFFICIENCY OF MEAT PRODUCTION FROM CULLED FORCE-FED LACTATING BUFFALO
}

\author{
Safaa S. A. Khalil \\ Buffalo Breeding Research Department, Animal Production Research Institute, \\ Agricultural Research Center, Ministry of Agricultural, Dokki, Giza, Egypt
}

\section{SUMMARY}

Efficiency of meat production from culled lactating buffalo after ending their lactation was investigated by exposing them to short finishing period of 56 days. Fourteen culled female buffalos were equally divided into two groups, force-fed (finished) and control, based on their averages of initial age (91.5 and 89.0 months, respectively) and live body weight (526.67 and $539.17 \mathrm{~kg}$, resp.). Finished group was fed on concentrate feed mixture (CFM), clover hay and rice straw in restricted diet regimen to fulfill nutrient requirements for $0.900 \mathrm{~kg}$ daily gain, whilst control group was fed the nutritional requirements for maintenance. Average body weight daily gain and dry matter intake were recorded fortnightly. At the end of finishing period, three animals from each group were slaughtered, and then the right sides of the carcasses were dissected into different cuts. Obtained results indicated that finishing regime improved the performance, carcass characteristics, carcass composition, and meat quality of buffalo cow. Force-fed group achieved higher $(P<0.05)$ average daily gain $(0.940 \mathrm{~kg})$, and hence recorded higher $(P<0.05)$ final body weight $(585.9$ $\mathrm{kg})$ than control group $(0.138 \mathrm{~kg}$ and $540.6 \mathrm{~kg}$, respectively). The improvement of carcass characteristics, carcass composition, and meat quality were remarkably observed in force-fed group, despite of the higher percentage of fat in longissimus dorsi muscle. Carcass weight and the percentages of dressing and boneless meat increased $(P<0.05)$ in the force-fed animals. The dressing and boneless meat percentages were $54.0 \%$ and $84.2 \%$ in the force-fed group; while it was $49.7 \%$ and $78.6 \%$ in the control one.

Lean percentage increased in force-fed buffalo by about $4 \%$ followed by higher lean / bone ratio (being 3.66 vs. 1.95). Neither internal nor external offals as a percentage from slaughter weight were affected significantly by finishing regime. In addition, meat quality of best ribs (9, 10, 11), namely physical and chemical characteristics, was improved by finishing regime. The obvious results indicated that culled lactating buffalo could be used efficiently in meat production when subjecting them to a short finishing period of 56 days. That encourages buffalo breeders to use these animals as a potential source of beef production after ending their lactation.

Keywords: Lactating buffalo, Force-fed, Carcass characteristics, Carcass composition, Meat quality

\section{INTRODUCTION}

Egypt has a severe shortage of animal proteins production especially throughout the last few years. Unfortunately, avian influenza caused an increase in red meat

Issued by The Egyptian Society of Animal Production 
consumption and consequently affected its price. The high prices having a serious impact on the poorest people drastically reducing their already low purchasing power thus, increased levels of food deprivation. The situation is getting very complex. Importing is not the ideal solution to solve this problem due to the economic limitations including international fluctuations, high foodstuff prices, and diseases. Efforts should be made to increase the efficiency of meat production from local livestock. Buffaloes contribute about $40 \%$ of the total meat production. In-spite of the prevailing notion that buffalo meat quality is inferior to bovine meat, buffalo meat is characterized with $40 \%$ less cholesterol, $12 \%$ less fat, $55 \%$ less calories, $11 \%$ more protein and $10 \%$ more mineral compared to bovine (Vale, 1996). Buffalo ends its productive life at approximately 67 to 77 months of age (Mohamed 1990) and culling percentage averaged $25 \%$ of the total herd. These culled animals are usually slaughtered without finishing and consequently, poor meat quantity and quality are expected. Previous research work on bovine and buffalo (Schnell, et al., 1997 and Khalil and Eid, 2004) indicated that there is an opportunity to exploit beef production from force-fed culled females for a short finishing period of 56 days; it is the most efficient of feed utilization leading to high and economical average daily gain,. However, studies on meat production and carcass quality from females are rare because the Egyptian regulations ban slaughtering of females. Therefore, this study uses culled lactating buffaloes to evaluate their efficiency in meat production by exposing them to 56 days of finishing period after ending their productive live.

\section{MATERIALS AND METHODS}

\section{Feeding and Management:}

The study was done during the period of September and November in MehalletMoussa Research Station, Buffalo Breeding Research Division, Animal Production Research Institute, Agricultural Research Centre, Egypt. Fourteen culled lactating buffalo were equally assigned to one of two groups, control and force-fed, based on their average initial age ( 90 months) and initial live body weight $(\sim 533 \mathrm{~kg})$. Control group was fed under routine feeding system adopted by governmental research stations for breeding. They were fed according to the nutritional requirements for maintenance (NRC, 1988). Force-fed group was individually kept in semi-open sheds, and fed on restricted diet regime with a higher level of concentrate (Ranjhan, 1999) for 56 days finishing period. Concentrate feed mixture (CFM), clover hay and rice straw were provided to fulfill nutrient requirements for $0.900 \mathrm{~kg}$ daily gain. CFM was composed of $25 \%$ yellow corn, $28 \%$ undecorticated cottonseed meal, $37 \%$ wheat bran, $7 \%$ molasses, $2 \%$ limestone and $1 \%$ common salt. The concentrate diet was offered twice daily, while clover hay and rice straw were given once a day. Fresh water was available two times a day and mineral blocks were freely available. Routinely, vitamins A and D (1 ml / kg body weight) were injected to all animals once throughout the experiment. Live body weight was measured fortnightly to calculate the average daily gain (ADG). In addition, feed intake was recorded two times monthly. Dry matter intake was calculated by weighing the feed distributed and the residue in the manger 24 hours later. The chemical composition of feeds was analyzed by AOAC (2000) official methods (Table 1). 
Table 1. Chemical composition (\%) of animals feeds on dry matter basis

\begin{tabular}{lccc}
\hline \multicolumn{1}{c}{ Item } & Concentrate & Clover hay & Rice straw \\
\hline Dry matter & 91.56 & 91.06 & 92.68 \\
Organic matter & 92.55 & 85.65 & 84.55 \\
Crude protein & 17.61 & 14.09 & 4.90 \\
Ether extract & 3.78 & 1.59 & 1.10 \\
Crude fiber & 14.65 & 30.41 & 33.83 \\
N. Free extract & 56.51 & 39.56 & 44.72 \\
Ash & 1.54 & 14.35 & 10.99 \\
\hline
\end{tabular}

Slaughtering and meat quality:

At the end of the trial, three animals from each group were slaughtered after 18 hours fasting period. Slaughter weight was recorded just prior to slaughter. After slaughtering, animals were dressed out and skinned, and then the following data were collected: weight of skin, head, hide, feet, tail, liver, spleen, heart, lungs with trachea, kidneys, full and empty small and large intestine and carcass. The carcass was split longitudinally into two halves and weighed. Then dressing percentage was calculated. The right side of each carcass was divided into major cut groups based on their quality into best (fore ribs, best ribs, sirloin, fillet, and round), medium (neck, brisket, shoulder and flat ribs) and inferior (fore shin, flank and hind shank) according to Weniger et al. (1963). The boneless meat was obtained when each of these cuts was dissected into meat and bones. Best ribs cut $\left(9,10\right.$ and $11^{\text {th }}$ ribs) was chilled for 24 hours at $4{ }^{0} \mathrm{C}$ then eye muscle area $\left(\mathrm{cm}^{2}\right)$ was measured at $10^{\text {th }}$ rib before dissection of chilled cut using LI-COR Area Meters. Best rib cuts were also dissected into lean, bone, and fat to calculate the ratios of lean/fat and lean/bone. Cooking loss percentage and the expressible fluid were determined according to Grau and Hamm (1956), and then stored at $-24{ }^{\circ} \mathrm{C}$ to study the chemical composition (AOAC, 2000).

\section{Statistical Analysis:}

The analysis of data was carried out by the least squares method, using the General Linear Model of SAS, 1999 according to the following model:

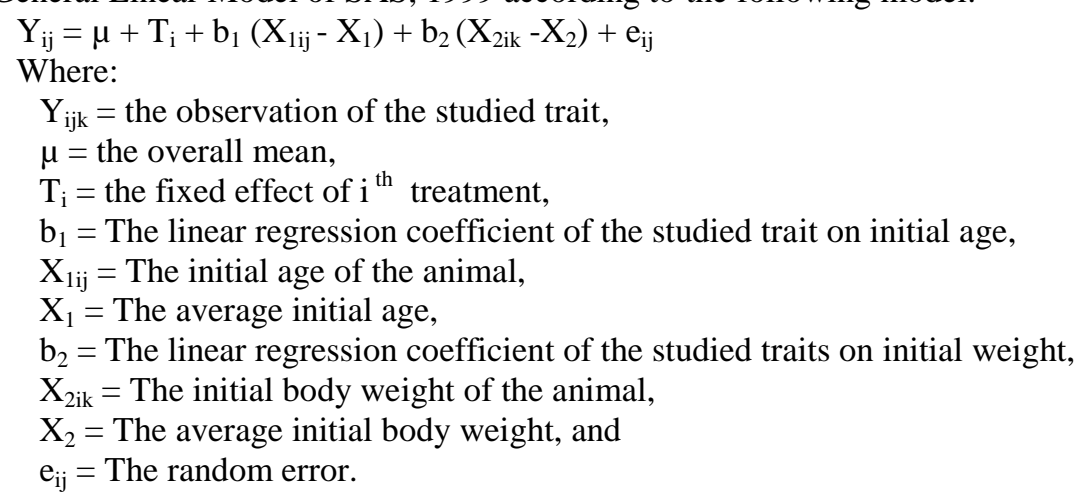

\section{RESULTS AND DISCUSSION}

\section{Performance:}

Least squares means of initial age and live body weight, the average daily gain in weight $(\mathrm{ADG})$, the final live body weight, and dry matter intake (DM) are presented 
in Table (2). Finishing regime improved $(P<0.05)$ the performance of culled lactating buffalo. Although, no significant differences were detected between groups in least squares means of the average initial body weight, nevertheless finished group showed more efficiency feed conversion than control one. Finishing regime increased ADG up to $0.940 \mathrm{~kg}$, and hence the final body weight increased to $585.9 \mathrm{~kg}$ compared to $0.138 \mathrm{~kg}$ and $540.6 \mathrm{~kg}$ for ADG and final body weight, respectively in control group. The differences in final body weight reflect the differences in ADG, which could be attributed to the improvement of digestion in finished animals that received higher $(\mathrm{P}<0.05)$ DM intake, especially concentrate diet (Table 2). Similar results were obtained by Schnell et al. (1997); Khalil (2000) and Khalil and Eid (2004) in culled female cows and buffaloes.

Table 2. The performance ( $\mathrm{LSM} \pm \mathrm{SE}$ ) of culled lactating buffalo under finishing regime for 56 days (n= 7 per group)

\begin{tabular}{lcc}
\multicolumn{1}{c}{ Items } & $(\mathbf{n = 7}$ per group $)$ \\
\hline Control group & Force-fed group \\
\hline Initial age, months & $89.0 \pm 16.85$ & $91.50 \pm 18.45$ \\
Initial live body weight, $\mathrm{kg}$ & $539.2 \pm 54.68$ & $526.7 \pm 54.11$ \\
Final live body weight, kg & $540.6^{\mathrm{a}} \pm 10.19$ & $585.9^{\mathrm{b}} \pm 10.19$ \\
Total body weight gain, $\mathrm{kg}$ & $7.70 \pm 10.19$ & $53.0 \pm 10.19$ \\
Average daily gain, $\mathrm{kg}$ & $0.138^{\mathrm{a}} \pm 0.18$ & $0.94^{\mathrm{b}} \pm 0.18$ \\
Dry matter intake, $\mathrm{kg}$ : & & \\
$\quad$ Concentrate & $300.8^{\mathrm{a}} \pm 28.16$ & $550.7^{\mathrm{b}} \pm 28.16$ \\
$\quad$ Clover hay & $25.5 \pm 0.00$ & $77 . \pm 0.00$ \\
$\quad$ Straw & $150.9 \pm 0.00$ & $103.8 \pm 0.00$ \\
Total dry matter & $477.2 \pm 28.16$ & $730.6 \pm 28.16$ \\
Feed conversion, kg/kg & & 13.80 \\
$\quad$ DM /Gain & 61.97 & \\
\hline Means within the same row with different superscripts differed significantly $(\mathrm{P}<0.05)$
\end{tabular}

\section{Carcass Traits:}

Carcass characteristics:

As shown in Table (3), finishing regime improved carcass traits of culled lactating buffaloes. A significant difference in live weight gain between groups was reflected in similar differences in carcass weight. Furthermore, finished group achieved higher $(P<0.05)$ dressing and boneless meat percentages than the control one. The dressing percentage was $54.0 \%$ and $49.7 \%$ for force-fed buffalo and control groups, respectively. This result could be due to the higher differences in carcass weight between groups studied. The corresponding values of boneless meat percentage were $84.2 \%$ and $78.6 \%$. The dressing and boneless meat values were nearly the same as that obtained by Zeidan et al. (1984) for female buffaloes slaughtered at three years of aged but higher than values of Houria and Omar (1994) and Khalil and Eid (2004) in culled female buffaloes older than 7-12 years and 40 months, respectively This could be attributed to the feeding regime, the time of feeding, etc. On the other hand, results of boneless meat could be confirmed by that recorded for the eye muscle area (EMA), which is a good indicator of lean percentage in carcass. It is clear that force-fed group recorded higher EMA than control one by about $10 \%$. The current values of EMA seem to be lower than those reported by 
Houria and Omar (1994) and Khalil (2000) in culled female buffaloes >7-12 years and 3.5 years old, respectively. That difference might be due to using the LI-COR Area Meters, which gives more precise results than the ordinary plannemeter (Khalil and Abdel Gawad, 2006).

Concerning carcass composition, Tables ( 3 and 4) indicate that the percentage of tissues in the best ribs cut of Longissimus dorsi muscle followed the same trend of the whole carcass. Finished group recorded higher percentage of lean by about $4 \%$ and higher ratio of lean/bone (3.66) than the control group (1.95). In addition, the increase in lean accompanied increase in fat yields in finished animals, whilst the ratio of lean/fat was almost the same in both groups. These results were in accordance with those obtained by Apple et al. (1999) and Khalil and Eid (2004) in culled females cow and buffalo. However, feeding concentrates resulted in lower proportion of the total fat being deposited as carcass fat in steers (Scollan et al., 2003).

Least squares means of separate cuts and different quality cut groups, namely, best (fore ribs, best ribs, sirloin, fillet, and round), medium (neck, brisket, shoulder and flat ribs) and inferior (fore shin, flank and hind shank), as a percentage of carcass weight are presented in Table (4). Finishing regime increased the percentage of meat in different quality cuts, best, medium, and inferior by about $5.9 \%, 6.7 \%$, and $7.2 \%$, respectively, in comparison with control group. Data shown in Table (4) were in harmony with previous data in Table (3). Force-fed group had insignificant higher percentage of meat in all separate cuts than control one. On the other hand, no differences were detected between groups concerning internal and external offals when calculated as a percentage of slaughter weight (Table 5).

Table 3. Least squares means $(\mathrm{LSM} \pm \mathrm{SE})$ of carcass traits of culled lactating buffalo ( $n=3$ per group)

\begin{tabular}{lcc}
\hline \multicolumn{1}{c}{ Items } & Control group & Force-fed group \\
\hline Initial age, months & $89.0 \pm 16.85$ & $91.50 \pm 18.45$ \\
Initial live body weight, kg & $539.2 \pm 54.68$ & $526.7 \pm 54.11$ \\
Slaughter weight, kg & $542.4^{\mathrm{a}} \pm 8.21$ & $603.2^{\mathrm{b}} \pm 8.21$ \\
Carcass weigh, kg & $267.4^{\mathrm{a}} \pm 5.60$ & $325.1^{\mathrm{b}} \pm 5.60$ \\
Dressing percentage & $49.7^{\mathrm{a}} \pm 0.84$ & $54.0^{\mathrm{b}} \pm 0.48$ \\
Boneless meat percentage & $78.6^{\mathrm{a}} \pm 1.00$ & $84.3^{\mathrm{b}} \pm 1.00$ \\
Meat / bone ratio & $5.20 \pm 1.45$ & $5.50 \pm 1.45$ \\
Eye muscle area, $\mathrm{cm}^{2}$ & $39.8 \pm 0.98$ & $43.8 \pm 0.76$ \\
Carcass composition \%: & & \\
$\quad$ Lean & $53.2 \pm 6.74$ & $56.7 \pm 6.74$ \\
$\quad$ Fat & $19.7 \pm 2.24$ & $27.9 \pm 2.42$ \\
$\quad$ Bone & $27.3 \pm 4.40$ & $15.5 \pm 4.40$ \\
Lean : fat ratio & 2.69 & 2.03 \\
Lean : bone ratio & 1.95 & 3.66 \\
\hline Mean whio & &
\end{tabular}

Means within the same row with different superscripts differed significantly $(\mathrm{P}<0.05)$ 
Table 4. Least squares means ( $L S M \pm S E)$ of different cuts as a percentage of carcass weights of culled lactating buffalo $(n=3$ / group)

\begin{tabular}{|c|c|c|c|}
\hline \multicolumn{2}{|c|}{ Items } & Control group & Force-fed group \\
\hline \multicolumn{2}{|l|}{ Initial age, mo } & $89.0 \pm 16.85$ & $91.50 \pm 18.45$ \\
\hline \multirow{2}{*}{\multicolumn{4}{|c|}{$\begin{array}{l}\text { Carcass weight, } \mathrm{kg} \\
\text { Different quality cuts, \% }\end{array}$}} \\
\hline & & & \\
\hline \multirow[t]{3}{*}{ Best quality cuts*: } & Total & $46.0 \pm 0.74$ & $44.9 \pm 0.74$ \\
\hline & Meat & $39.1 \pm 1.51$ & $41.43 \pm 1.51$ \\
\hline & Bone & $9.2 \pm 1.18$ & $6.1 \pm 1.10$ \\
\hline \multicolumn{2}{|c|}{ Medium quality cuts**: Total } & $35.0 \pm 1.34$ & $35.2 \pm 1.34$ \\
\hline & Meat & $28.1 \pm 0.90$ & $30.0 \pm 0.9$ \\
\hline & Bone & $6.9 \pm 0.52$ & $5.2 \pm 0.52$ \\
\hline & Inferior quality cuts ${ }^{* * *}$ : Total & $16.7 \pm 0.93$ & $17.2 \pm 0.93$ \\
\hline & Meat & $12.0 \pm 1.03$ & $12.9 \pm 1.03$ \\
\hline & Bone & $4.6 \pm 0.20$ & $4.3 \pm 0.20$ \\
\hline \multirow[t]{3}{*}{ Fore shank: } & Total & $3.6 \pm 0.11$ & $3.2 \pm 0.11$ \\
\hline & Meat & $2.1 \pm 0.16$ & $1.7 \pm 0.16$ \\
\hline & Bone & $1.5 \pm 0.21$ & $1.6 \pm 0.21$ \\
\hline \multirow[t]{3}{*}{ Neck: } & Total & $9.3 \pm 1.23$ & $7.6 \pm 1.23$ \\
\hline & Meat & $7.6 \pm 1.24$ & $6.6 \pm 1.24$ \\
\hline & Bone & $1.7 \pm 0.26$ & $0.9 \pm 0.26$ \\
\hline \multirow{3}{*}{ Shoulder: } & Total & $12.6 \pm 1.09$ & $14.4 \pm 1.09$ \\
\hline & Meat & $10.3 \pm 1.21$ & $12.5 \pm 1.21$ \\
\hline & Bone & $2.4 \pm 0.12$ & $1.9 \pm 0.18$ \\
\hline \multirow[t]{3}{*}{ Fore ribs: } & Total & $9.6 \pm 1.01$ & $7.2 \pm 1.01$ \\
\hline & Meat & $7.3 \pm 0.47$ & $6.0 \pm 0.47$ \\
\hline & Bone & $2.3 \pm 0.58$ & $1.1 \pm 0.58$ \\
\hline \multirow[t]{3}{*}{ Flat ribs: } & Total & $7.1 \pm 0.68$ & $7.3 \pm 0.68$ \\
\hline & Meat & $5.5 \pm 0.56$ & $6.2 \pm 0.56$ \\
\hline & Bone & $1.6 \pm 0.37$ & $1.2 \pm 0.37$ \\
\hline \multirow[t]{3}{*}{ Brisket: } & Total & $6.0 \pm 1.05$ & $6.0 \pm 1.05$ \\
\hline & Meat & $4.7 \pm 1.10$ & $4.7 \pm 1.10$ \\
\hline & Bone & $1.3 \pm 0.13$ & $1.2 \pm 0.13$ \\
\hline \multirow[t]{3}{*}{ Hind shin: } & Total & $3.8 \pm 0.08$ & $3.4 \pm 0.08$ \\
\hline & Meat & $1.7 \pm 0.05$ & $1.8 \pm 0.05$ \\
\hline & Bone & $2.0 \pm .05$ & $1.6 \pm 0.05$ \\
\hline \multirow[t]{3}{*}{ Flank: } & Total & $9.3 \pm 1.24$ & $10.6 \pm 1.24$ \\
\hline & Meat & $8.2 \pm 1.00$ & $9.5 \pm 1.00$ \\
\hline & Bone & $1.1 \pm 0.12$ & $1.1 \pm 0.12$ \\
\hline \multirow[t]{3}{*}{ Round: } & Total & $29.1 \pm 1.39$ & $29.6 \pm 1.39$ \\
\hline & Meat & $24.7 \pm 1.73$ & $25.8 \pm 1.73$ \\
\hline & Bone & $4.4 \pm 0.35$ & $3.8 \pm 0.35$ \\
\hline \multicolumn{2}{|l|}{ Fillet } & $2.3 \pm 0.13$ & $2.6 \pm 0.13$ \\
\hline \multirow[t]{3}{*}{ Sirloin: } & Total & $4.8 \pm 0.43$ & $5.4 \pm 0.43$ \\
\hline & Meat & $3.1 \pm 0.18$ & $4.6 \pm 0.18$ \\
\hline & Bone & $1.8 \pm 0.25$ & $0.7 \pm 0.25$ \\
\hline \multirow[t]{4}{*}{ Best ribs: } & Total & $2.4 \pm 0.13$ & $2.8 \pm 0.13$ \\
\hline & Lean & $1.3 \pm 0.11$ & $1.6 \pm 0.11$ \\
\hline & Fat & $0.5 \pm 0.12$ & $0.8 \pm 0.12$ \\
\hline & Bone & $0.7 \pm 0.14$ & $0.4 \pm 0.14$ \\
\hline
\end{tabular}

Means within the same row with different superscripts differed significantly $(\mathrm{P}<0.05)$.

*Best quality cuts (Round, sirloin, fore ribs, best ribs, and fillet). **Medium quality cuts (Shoulder, brisket, flat ribs and neck). ***Inferior quality cuts (Flank, fore shin and hind shank). 
Table 5. Least squares means $(\mathrm{LSM} \pm \mathrm{SE})$ of internal and external offals as a percentage of slaughter weight of culled lactating buffalo

\begin{tabular}{lcc}
\multicolumn{1}{c}{ Item } & Control group & Force-fed group \\
\hline Initial age, mo & $89.0 \pm 16.85$ & $91.50 \pm 18.45$ \\
Slaughter weight, kg & $542.4^{\mathrm{b}} \pm 8.21$ & $603.2^{\mathrm{a}} \pm 8.21$ \\
Internal offal's, \% & & \\
Liver & $1.02 \pm 0.04$ & $1.23 \pm 0.04$ \\
Spleen & $0.21 \pm 0.01$ & $0.18 \pm 0.01$ \\
Heart & $0.39 \pm 0.03$ & $0.45 \pm 0.03$ \\
Kidneys & $0.27 \pm 0.06$ & $0.31 \pm 0.06$ \\
Lungs \& trachea & $1.99 \pm 0.05$ & $1.88 \pm 0.06$ \\
External offal's, \% & & \\
Head & $5.24 \pm 0.23$ & $4.19 \pm 0.23$ \\
Hide & $7.65 \pm 0.15$ & $8.90 \pm 0.15$ \\
Feet & $2.41 \pm 0.06$ & $2.29 \pm 0.06$ \\
FRG & $12.87 \pm 1.08$ & $10.83 \pm 1.08$ \\
ERG & $4.30 \pm 0.4$ & $4.58 \pm 0.4$ \\
Full intestine & $5.32 \pm 0.77$ & $4.68 \pm 0.77$ \\
Empty intestine & $2.88 \pm 0.38$ & $3.79 \pm 0.47$ \\
Tail & $0.26 \pm 0.03$ & $0.31 \pm 0.03$ \\
\hline
\end{tabular}

Means within the same row with different superscripts differed significantly $(\mathrm{P}<0.05)$

\section{Meat Quality:}

\section{Physical and chemical characteristics}

Least squares means of the expressible fluid and cooking loss percentages and chemical composition of longissimus dorsi muscle are presented in Table (6). Improvement of meat quality was remarkably observed in force-fed animals. Finished group showed lower percentage of expressible fluid and cooking loss than control (being $32.5 \%$ and $44.96 \%$ versus $39.13 \%$ and $45.76 \%$, respectively). Water holding capacity was enhanced by decreasing the percentage of the expressible fluid. Lower expressible fluid in finished group may be attributed to the compact firmness of their muscle. The decreasing of cooking loss percentage with decreasing the percentage of expressible fluid was noticeable in finished group. That conclusion was supported by Lawrie (1974) who indicated that cooking loss was diminished by enhancing water-holding capacity. Similar findings were obtained by Khalil (2000) in finished culled buffalo heifers at younger age (36-40 months) with lower values.

On the other hand, insignificant differences were found between groups concerning chemical composition of Longissimus dorsi muscle as shown in Table (6). However, finishing regime improved marbling of the Longissimus dorsi muscle by increasing intramuscular fat compared to control animals (3.39\% versus $1.87 \%)$. In addition, finished group recorded lower moisture content. Results obtained were in full agreement with that found by Matulis et al. (1987), Faulkner et al. (1989), Cranwell, et al. (1996) and Schnell et al. (1997). They suggested that the higher content of intramuscular fat in meat was accompanied by lower content of moisture in cull beef cows when exposing them to 56 days concentrate feeding period.

It can be concluded from the previous discussion that finishing of culled lactating buffalo for a short period of 56 days was sufficient to improve the performance, carcass characteristics, carcass composition, and meat quality after ending their 
productive life. The average daily gain reached $0.940 \mathrm{~kg}$; the dressing and boneless meat percentages increased, $54.0 \%$ and $84.2 \%$, respectively; lean percentage increased by about $4 \%$, lean/bone ratio reached 3.7 , and meat quality was improved. Furthermore, exposing such animals for a short finishing period is recommended to buffalo breeders to use it as a potential source of beef production.

Considering these results, there is particular need for further economic research on culled female buffalo as a potential source of meat production.

Table 6. Least squares means ( $\mathrm{LSM} \pm \mathrm{SE})$ of some physical and chemical characteristics of Longissimus dorsi muscle in culled lactating buffalo

\begin{tabular}{ccc} 
& & (n=8/group) \\
\hline Item & Control group & Force-fed group \\
\hline $\begin{array}{c}\text { Carcass characteristics, \% } \\
\text { Cookring loss }\end{array}$ & $39.1 \pm 4.20$ & $32.0 \pm 3.38$ \\
Chemical characteristics, $\%$ & $45.8 \pm 3.16$ & $45.0 \pm 2.54$ \\
Moisture & & \\
DM & $73.8 \pm 1.55$ & $71.8 \pm 1.25$ \\
CP & $26.2 \pm 1.55$ & $28.2 \pm 1.25$ \\
EE & $23.5 \pm 1.06$ & $23.2 \pm 0.85$ \\
Ash & $1.9 \pm 0.22$ & $3.4 \pm 0.18$ \\
\end{tabular}

Means within the same row with different superscripts differed significantly $(\mathrm{P}<0.05)$

\section{REFERENCES}

A.O.A.C., 2000. Official methods of analysis. $17^{\text {th }}$ ed. Association of Official Analytical Chemists, Washington, DC.

Apple, J. K., J. C. Davis, J. Stephenson, J. E. Hankins, J. R. Davis and S. L. Beaty, 1999. Influence of body condition score on carcass characteristics and sub primal yield from cull beef cows. J. Anim. Sci., 77: 2660-2669.

Cranwell, C. D. J. A. Unruh; J.R. Brethour D. D. Simms and R. E. Campbell, 1996. Influence of steroid implants and concentrate feeding on performance and carcass composition of cull beef cows. J. Anim. Sci., 74: 1770.

Faulkner, D. B. F. K. Mckeith, L. L. Berger, D. J. Kesler and D. F. Parrett 1989. Effect of testosterone propionate on performance and carcass characteristics of heifers and cows. J. Anim. Sci., 67: 1907- 1915.

Fiems, L. O., C.V. Boucque, D.L. Brabander and B.G. Cottyn, 1995. The effect of the $\beta$-adrenergic agonist Cimaterol on performance and carcass and meat quality in culled dairy cows. J. Anim. Sci., 61: 19-23.

Grau, R. and Hamm, 1956. Die Bestimmung des Wasserbindung des Fleiches mittelsder Pressmethode. Die Fleischwirtschaft, 36: 733 (Cited in Fiems et al., 1995).

Houria, M. A. and S.S. Omar, 1994. Evaluation of meat production from culled female buffaloes. Egypt. J. Anim. Prod., 31: 1-14.

Khalil, Safaa S. A., 2000. Effect of some natural additives on meat production from buffaloes. Ph. D. Thesis, Fac. of Agric., Cairo Univ.

Khalil, Safaa S. A. and Laila, N. Eid, 2004. Culled buffalo heifers as a potential source for beef production. J. Agric. Sci. Mansoura Univ., 29 (9): 4903-4916. 
Khalil, Safaa S. A. and M. H. Abdel Gawad, 2006. Impact of natural growth stimulants supplemented diets on performance, carcass characteristics, and feasibility of finishing culled female buffalo. Egypt. J of Anim. Prod.,43: 185198.

Lawrie, R. A., 1974. Meat Science. Text Book, $2^{\text {nd }}$ edition, Pergmon Press, Oxford, New York, Toronto Sydney, Braunsch-weig.

Mohamed, Set El-Habaeb, 1990. Genetic and phenotypic parameters of lifetime production traits in Egyptian buffaloes. M.Sc. Thesis, Tanta University, Faculty of Agric., Anim. Prod. Dept.

Matulis, R. J.; F. K. Mckeith; D. B. Faulkner; L. L. Berger and P. George, 1987. Growth and carcass characteristics of culled cows after different times on feed. J. Anim. Sci., 65: 669.

NRC, 1988. National Research Council. "Nutrient requirements of dairy cattle". $6^{\text {th }}$ Rev. Ed., National Academy of Science, Washington, D. C.

Ranjhan, S. K., 1999. Animal nutrition and feeding practices. Sixth Revised Edition, VIKAS Publ. House PVTLTD.

SAS Institute INC., 1999. Cary, NC., USA. Ver. 6.12.

Schnell, T. D., K. E. Belk, J. D. Tatum, R. K. Miller and G. C. Smith, 1997. Performance, carcass and palatability traits for cull cows fed high-energy concentrate diets for 0, 14, 28, 42 or 56 days. J. Anim. Sci., 75: 1195-1202.

Scollan, N. D., M. S. Dhanoa, E. J. Kim, J. M. Dawson and P. J. Buttery, 2003. Effects of diet and stage of development on partitiong of nutrients between fat and lean deposition in steers. Anim. Sci., 76: 237-249.

Vale, W. G., 1996. Reproductive management of water buffalo under Amazone conditions. International Symposium on buffalo products., Italy, 1-4, December, 1994, FAO- Interregional Cooperative Research Network on buffalo working Group Products, EAAP Publication, No., 82.

Weniger, J.H, D. Steinhauf and G. H. M. Pahl, 1963. Muskeltopographie der Schlachtkorper. Muscular Topography of carcasses. Text Book, BLV verlagsgesellschaft Munchen Basel Wien, Germany.

Zeidan, M., A. Taha, M.F. Sedik, and S. Roushdy, 1984. Efficiency of Egyptian buffaloes as meat produced animals. Egypt. J. Anim.. Prod., 24: 107-110. 
كفاعة إنتاج اللحم من الجاموس الحلاب المستبعد بتسمينه لمدة \ه يوم

صفاء شعبان احمد خليل

قسم بحوث تريبية الجاموس، معهل بحوث الإتتاج الحيوانس، مركز البحوث الزراعية، وزلرة النزاعة، الدقى،

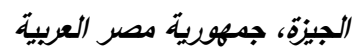

درست كفاءة إنتاج اللحم من الجاموس الحلاب المستبعد بعد انتهاء فتزرة الحليب بتعرضده لفترة تنوية قصيرة

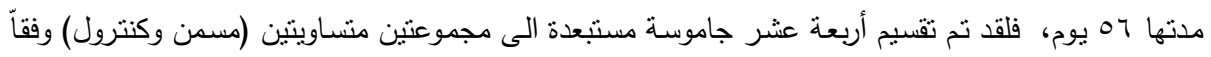

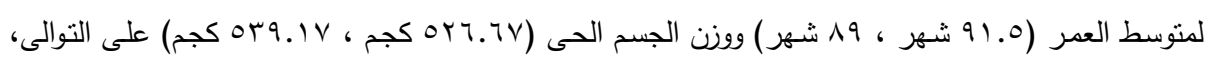
وغذيت المجموعة المسمنة وفقاً لنظام غذائى محدد للحصول على زيادة وزنية يومية قدرها . .9. . كجم وغذيت

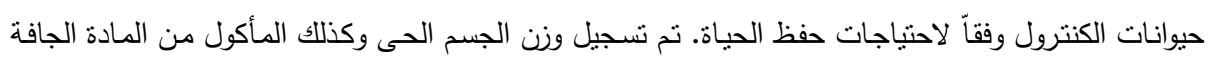

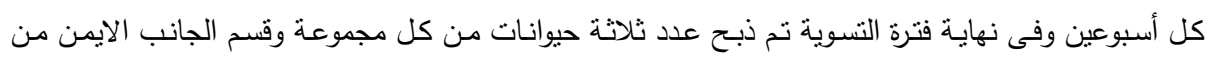
الذبائح الى قطعيات مختلفة.

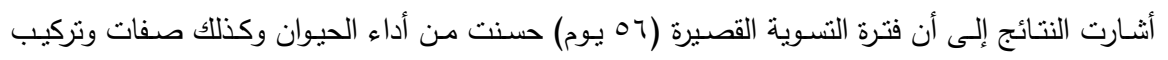

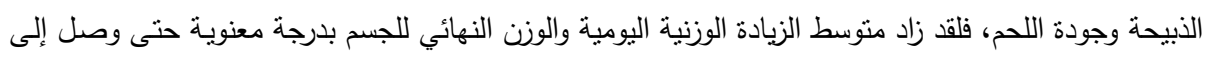

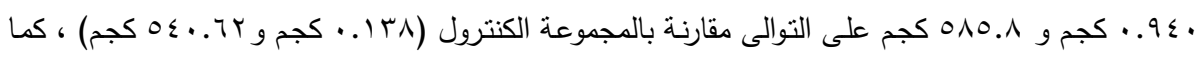

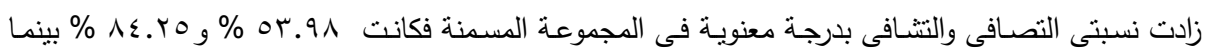

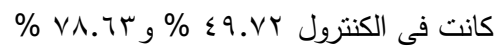

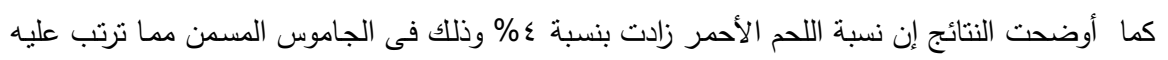

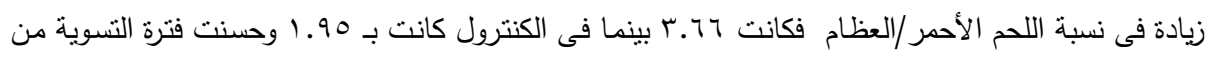
جودة اللحم وذلك من خلال تحسين الصفات الطبيعية والكيماوية للعضلة العينية.

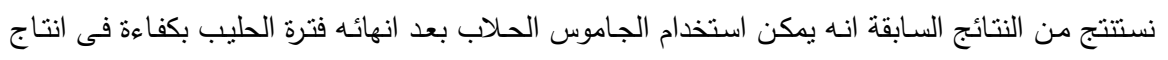

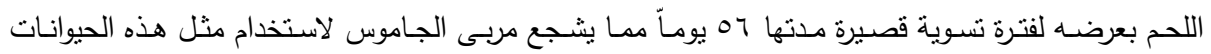
كمصدر جيد لانتاج اللحم لمرضن 